\title{
The Impact of Domestic Mergers and Acquisitions on the Operating Profit Margins of Companies in Russia
}

Vitaly Mikhalchuk

Research Supervisor

$\underline{\text { ORCID }}$

E-mail: vitalymikhalchuk@gmail.com

Deloitte, 125047 Lesnaya str., 5, Moscow, Russia

Journal of Corporate Finance Research, Vol. 14, No. 1, pp. 69-79 (2020)

DOI: https://10.0.67.171/j.jcfr.2073-0438.14.1.2020.69-79

Received 11 February 2020 | Peer-reviewed 17 March 2020 | Accepted 20 March 2020 


\section{The Impact of Domestic Mergers and Acquisitions on the Operating Profit Margins of Companies in Russia}

\section{Abstract}

This research paper studies the impact of domestic Russian mergers and acquisitions on the operating profit margin of companies participating in deals. The goal of the research is to evaluate the changes in operating profit margin, and to analyse the significance of factors affecting operating profit margin after deals have been concluded.

The main scientific contribution of this research is the development of a methodology to analyse the effect of mergers and acquisitions on operating profit margins that takes into account the idiosyncratic features of the Russian market, and which can be used with limited information for analysis of private companies. The proposed methodology is based on benchmarking the operating profit margin of companies participating in a deal against the same variable for a portfolio of similar companies.

Based on the analysis of recent studies, several explanatory variables were proposed to explain the changes in operating profit margin after the deal. Among these were included real GDP growth, type and value of the deal, book value of assets of the target company, as well as a number of control variables. A random effects model with robust standard errors was used to test the significance of factors affecting operating profit margin. This methodology was applied to a sample of 73 domestic Russian deals observed in the period 2012-2019.

This research makes several practical contributions to the literature. In the studied sample, deals lead to an increase of operating profit margin by $4.6 \%$ relative to the period before the deal, and $2.5 \%$ relative to the benchmark portfolio. The highest growth of operating profit margin relative to the benchmark portfolio is observed 2 years after the deal. This growth is increased by the purchase of large companies in the same industry. There is a significant negative effect of the deal value and a strong indication that buyers tend to overpay for the target companies relative to their fair value. This research will be of practical use for persons in management positions to estimate the value of prospective deals, and for academic researchers interested in the analysis of mergers and acquisitions in emerging markets.

Keywords: mergers; acquisitions; synergy; operating profit margin; market power, economies of scale; emerging markets JEL: G34 
Figure 1. Russian M\&A market in 2008-2019, billion USD

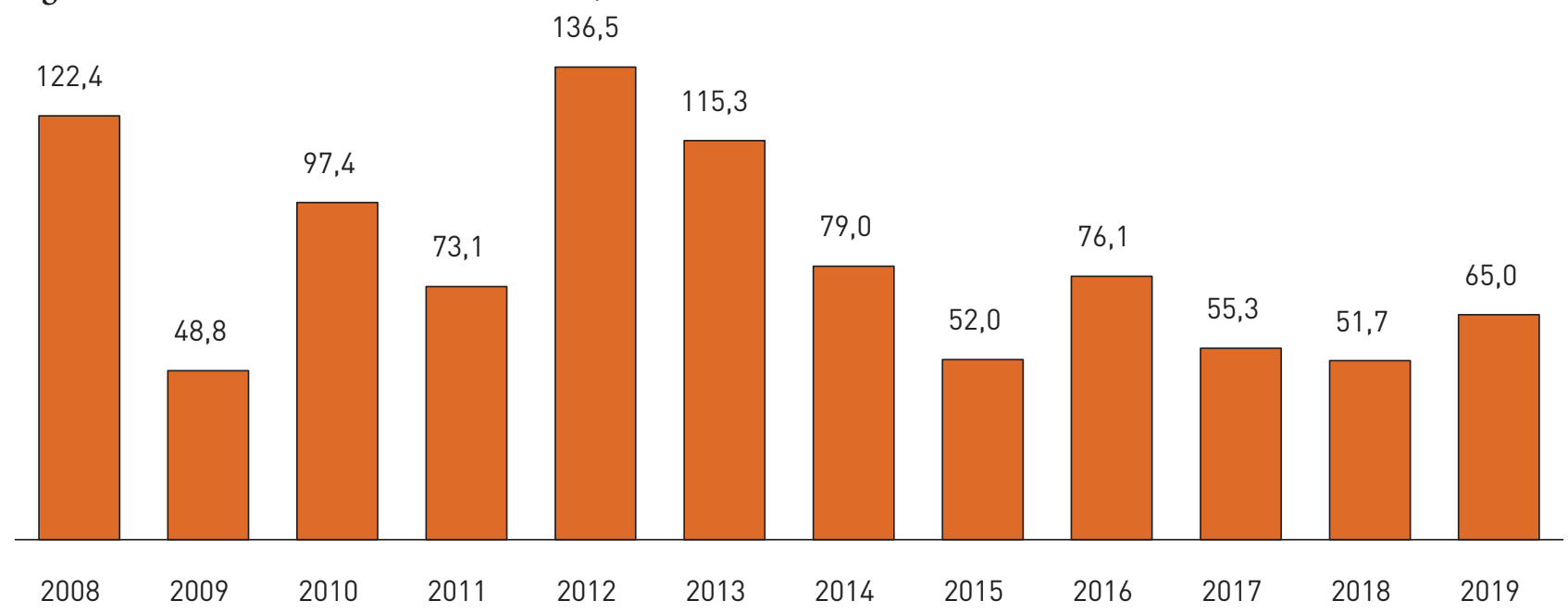

Source: Author's analysis based on KPMG data

\section{Introduction}

Every year, a significant amount of assets is involved in mergers and acquisitions (M\&A). In 2019, the global M\&A market amounted to USD 4.1 trillion $(-0.5 \% \mathrm{y} / \mathrm{y}){ }^{1}$ Despite the decline in global M\&A activity in 2019, companies continue to use M\&A to strengthen their business, enhance the scale of their operations and better position themselves in the global market.

The Russian M\&A market stagnated in the last 5 years. The economic sanctions against Russia adopted in March 2014 resulted in a decrease in domestic activity due to limited access to capital for many Russian companies. Low oil prices and the devaluation of the ruble at the end of 2014 further limited M\&A activity. In 2019, the Russian M\&A market amounted to USD 62.8 billion (670 deals $)^{2}$, which was over two times lower than in 2012 in terms of value.

The market is traditionally dominated by domestic deals, which accounted for $64 \%$ of market value in $2019.33 \%$ of the market accounted for the purchases of Russian assets by foreign companies, and only $3 \%$ were the purchases of foreign assets by Russian companies.

For the ten year period preceding 2019, the Oil and gas industry has remained the largest industry in terms of value. This industry accounted for about a third of all Russian deals in 2019. Other major industries by the factor of total deal value are banking, IT, metals and mining, telecommunications, and media. More than $80 \%$ of all such deals were between private companies. ${ }^{3}$

Due to uncertainty about the future of the Russian economy, many M\&A initiatives are currently postponed. In the current condition of the Russian M\&A market, it has become increasingly important to analyse the prospects of potential M\&A and, if possible, to better assess potential synergy. A topical research issue is the development of tools for empirical analysis of domestic deals, which takes into account the features of the national M\&A market and which can be used with limited information about companies.

This study is devoted to the development and application of these tools on a sample of 73 domestic Russian deals observed in 2012-2019. The study also attempts to estimate the impact of several features of Russian M\&A on operating profit margin. In this context, significant government involvement in the economy and high concentration of ownership in companies' equity capital (with control variables included in the econometric model), as well as the high share of domestic deals with the corresponding restriction are included within the sample.

\section{Literature review}

Shareholders expect the value of their company to increase as a result of M\&A. This additional value can be driven by the improved performance of assets (higher revenue, lower expenses, etc.), reduced discount rate for future cash flows, or other reasons. Studying the performance after M\&A is a simple approach to determining whether or not additional value was created.

In the existing literature, there are several ways to examine specific changes in performance after M\&A: first, examinations of ex-post stock price behaviour [1], [2]; second, studies of changes in specific characteristics of the firms [3]; third, studies of changes in operating performance [4], [5].

\footnotetext{
${ }^{1}$ J.P. Morgan 2020 Global M\&A Outlook. Retrieved February 05, 2020, from https://www.jpmorgan.com/jpmpdf/1320748081210.pdf

${ }^{2}$ KPMG Russian M\&A review 2019. Retrieved April 18, 2020, from https://assets.kpmg/content/dam/kpmg/ru/pdf/2020/02/ru-ru-ma-survey-2019.pdf

${ }^{3}$ Author's estimations based on Mergermarket.com data
} 
Figure 2. Structure of the Russian M\&A market in 2008-2019 by type, \% of billion USD

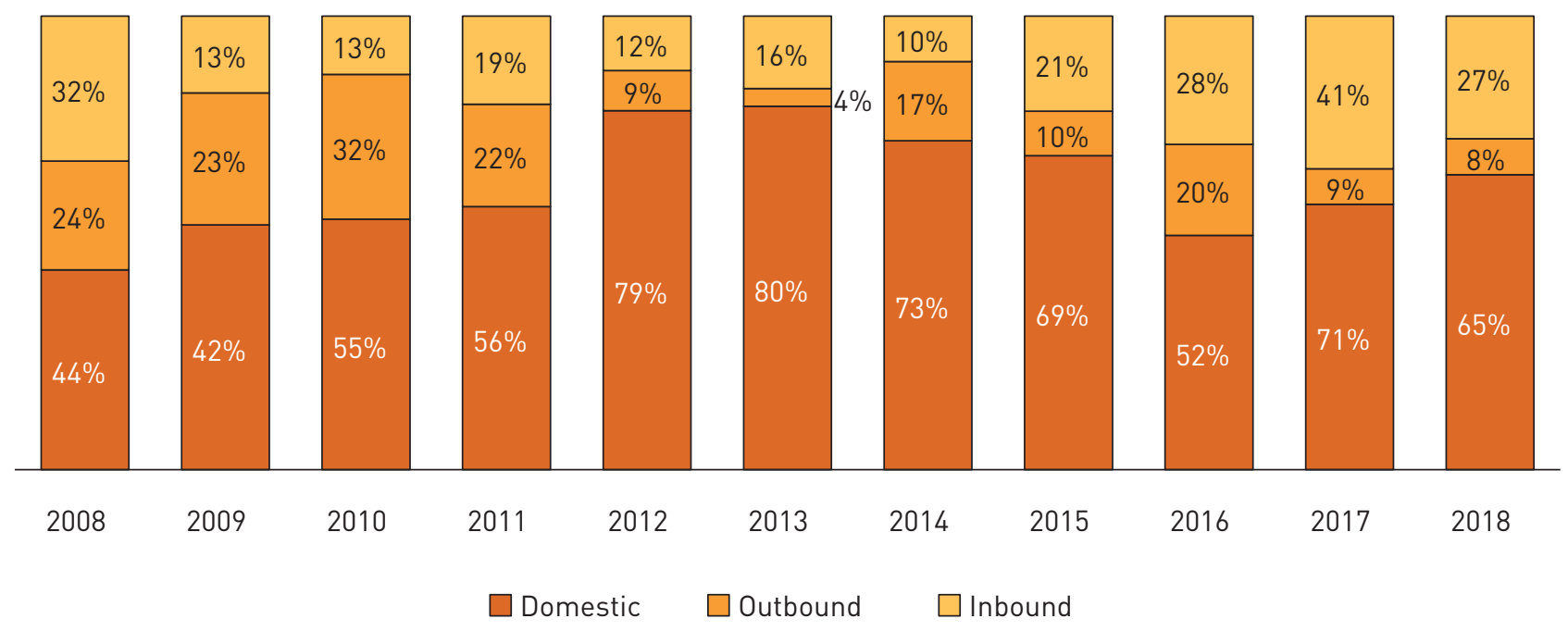

Source: Author's analysis based on KPMG data

This study focuses on the analysis of changes in operating performance, in particular, changes in the operating profit margin of companies involved in M\&A. The research design was similar to the one proposed in the recent paper by [5], which used return on assets and return on equity as the relevant performance indicators for analysis after the deal.

M\&A can affect the profitability of companies involved in a deal in two ways. First, increased revenue with stable expenses indicates that a merged company strengthened its market power, and is thus able to set prices higher than marginal costs, or at another level allowed by the competition prior to the deal. Second, decreased expenses with stable revenue indicate that cost reduction synergies were achieved after the deal.

Market power in academic and applied research is usually measured with a market share or market concentration index (Herfindahl-Hirschman index).

Using market share as an indicator of market power, the research at [6] (for deals in the United States in 1997-2007) and [7] (for deals in Europe in 1996-2010) showed that a growth of market share leads to a significant increase in ROI while maintaining the same level of expenses.

Studies based on the PIMS database (Profit Impact of Market Strategy) confirm a positive correlation between profitability and market share. The first studies on this topic, for example, [8] showed that a $10 \%$ increase in market share leads to a $5 \%$ increase in profit margin before taxes. The study of recent PIMS data by [9] also noted a significant positive correlation between changes in market share and earnings.

Expenses can decrease after a deal due to the optimisation of production and duplicative business functions (HR, IT, accounting, procurement, administrative and other). The total output and revenue do not change. These cost economies are estimated, with the average costs, output elasticities, or cost elasticities considered.
A majority of studies confirm that consolidation and integration via M\&A or other means lead to a cost reduction. This conclusion is supported by [10] in a study on international airports, [11] in European banking, and [12] for Russian natural monopolies.

This research attempts to estimate the significance of 4 variables that may explain the changes in operating profit margin after a deal. These variables are: changes in real gross domestic product (GDP), the type of deal (horizontal or vertical), the deal value, and the size of a target company. Real GDP growth is correlated with the value of the national M\&A market (see [13]), but may not affect M\&A synergies. For example, [14] showed, on a sample of 132 M\&A deals in the banking industry, that GDP growth is insignificant to the accumulated abnormal return of the buyer company's shares after M\&A.

Horizontal transactions may increase operating profit margin by gaining greater market share and creating economies of scale. Vertical transactions aim to increase control over the value chain and increase operating profit margin by reducing the costs of products or services. Studies show that horizontal deals are more likely to increase operating profit margin. The research at [15], on a sample of 90 French listed companies M\&A, and [16] on a sample of 434 Chinese M\&A, both concluded that horizontal M\&A lead to a cost reduction via economies of scale.

The increase in the deal value in most studies is associated with the destruction of synergy. For example, in [17] authors found a negative correlation between the size of the deal and the operating profit margin of the company after the deal. This may be explained by the systematic overpayment in the acquisition of large companies.

There are different views in the academic literature on the impact of the size of a target company on improving profitability after M\&A. One hypothesis is that the acquisition of a large company may create economies of scale, market power, and other types of synergies. On the other hand, large transactions may reduce the operating profit margin 
because of the complexity of integrating a large company into the overall business.

In the existing literature on the subject, the Russian M\&A market is usually included in the samples of M\&A projects in BRICS countries. Among examples in recent literature, [18] studies the impact of M\&A on corporate debt, [19] - on companies' fundamental values, and [20] on bidders' returns in financial sector.

\section{Research hypotheses}

After the analysis of relevant academic literature, 5 hypotheses related to the impact of M\&A on operating profit margin were formulated and tested in this study (Table 1). The expected signs for hypotheses are based on the assumption that signs of explanatory variables are the same in the Russian M\&A market as they are in other M\&A markets, as studied in the existing literature.

Table 1. Research hypotheses

$\begin{array}{llll}\text { Hypothesis } & \text { Variable } & \text { Expected sign } & \text { Literature } \\ \begin{array}{lll}\text { 1. Operating profit margin increases } \\ \text { after M\&A }\end{array} & \begin{array}{l}\text { Operating profit margin adjust- } \\ \text { ed for a benchmark based on } \\ \text { matching companies }\end{array} & \begin{array}{l}\text { Positive } \\ .\end{array}\end{array}$

2. Economic growth increases operat- Real GDP growth in Russia Positive ing profit margin

3. M\&A between companies in the same industry increase operating profit margin
Dummy variable (1 for horizon- Positive

[15], [16]

tal deals)

\section{More expensive M\&A reduce oper- Natural logarithm of deal value Negative ating profit margin}

5. M\&A of larger companies increase operating profit margin

Source: Author's analysis
Natural logarithm of target com- Positive pany assets value
[17]

\section{Data and methodology}

In order to compile the sample for this research, information was taken from several commercial databases (Mergermarket, SPARK-Interfax, Bloomberg), open government data (Rosstat, Central Bank of Russia), as well as unstructured information from the websites of the companies involved in the relevant transactions.

Initial data on domestic M\&A transactions were provided by the Mergermarket database. The total number of completed domestic transactions is 309 . The initial sample includes all domestic deals in the database completed in the period under review. Transactions between companies in regulated industries and the financial industry were excluded from the initial sample due to the features of reporting and operating profit margin measures in these industries.

Data on the financial performance of companies involved in M\&A were collected from SPARK-Interfax and Bloomberg databases. Financial data used to calculate operating profit margin included revenue and operating profit details. The primary sources of financial information for the SPARK-Interfax and Bloomberg databases were annual profit and loss statements.

The sample included financial indicators for 7 years: 3 years before M\&A, in the year of M\&A and 3 years after
M\&A. If during the 3 years after the deal one or both companies were involved in another M\&A transaction, terminated operations, or did not publish data needed for the analysis, the time period was reduced to obtain comparable data.

The time period under review was at least three years (a year before M\&A, a year of M\&A and a year after M\&A). It was assumed that the operating profit margin is affected within no more than three years from M\&A completion date.

M\&A deals where the book value of the target company's assets in the year of M\&A was less than 5\% of the buyer's assets were also excluded. Following the example of [22], it was assumed that M\&A deals have a significant impact on the buyer's operating profit margin only under this restriction. The final sample contains 73 deals and 446 individual observations of operating profit margin in 2012-2019.

A detailed description of all reasons for excluding M\&As from the general sample is provided in Table 2.

All deals included in the final sample involved an acquisition of the controlling stake. 23 deals also involved integration of businesses after a deal. The composition of the initial and the final samples is provided in Table 3. 
Table 2. Excluded deals and the final sample

Reasons of exclusion
Initial sample
No financial statements
Deals do not change the holder of the controlling stake
Deals between companies in the financial industry

Source: Author's analysis

Table 3. The composition of the initial and the final samples

\begin{tabular}{|c|c|c|}
\hline & Initial sample & Final sample \\
\hline Total deals & 309 & 73 \\
\hline \multicolumn{3}{|l|}{ Payment } \\
\hline Cash & 128 & 28 \\
\hline Shares & 9 & 2 \\
\hline No data & 172 & 43 \\
\hline \multicolumn{3}{|l|}{ Primary industry } \\
\hline Consumer and agriculture & 53 & 13 \\
\hline Banking and insurance & 40 & 0 \\
\hline Oil and gas & 32 & 7 \\
\hline Telecoms and media & 28 & 9 \\
\hline Real estate and construction & 26 & 14 \\
\hline Manufacturing & 24 & 9 \\
\hline $\mathrm{R} \& \mathrm{D}$ and technologies & 18 & 2 \\
\hline Transport & 17 & 8 \\
\hline Metals and mining & 13 & 4 \\
\hline Other & 58 & 7 \\
\hline \multicolumn{3}{|l|}{ Deal value, million USD } \\
\hline Average & 549 & 710 \\
\hline Median & 112 & 133 \\
\hline Minimum & 5 & 14 \\
\hline Maximum & 11270 & 8411 \\
\hline
\end{tabular}

Source: Author's analysis 
The operating profit margin for every deal was measured as the sum of operating profit margins of buyer and target companies weighted by their revenue before and after the deal.

$$
\begin{aligned}
& \text { Operating profit margin }_{i t}=\frac{\text { EBIT }_{i, t, \text { buyer }}}{\text { Revenue }_{i, t, \text { buyer }}} \cdot \\
& \cdot \frac{\text { Revenue }_{i, t, \text { buyer }}}{\text { Revenue }_{i, t, \text { buyer }}+\text { Revenue }_{i, t, \text { target }}}+ \\
& +\frac{\text { EBIT }_{i, t, \text { target }}}{\text { Revenue }_{i, t, \text { target }}} \cdot \frac{\text { Revenue }_{i, t, \text { target }}}{\text { Revenue }_{i, t, \text { buyer }}+\text { Revenue }_{i, t, \text { target }}}
\end{aligned}
$$

where $i$ is the index of deals and $t$ is the index of time (years of observation for each deal). These data were from the annual financial statements of buying and target companies. After the deal, if available, the consolidated financial statements of the buyer were used to calculate operating profit margin for both companies.

To account for the differences in operating profit margin in various industries, the operating profit margin of the benchmark portfolio of comparable companies for every deal was also calculated.

The benchmark portfolio included 4 companies in the same industry under the three-digit code of OKVED and with the closest revenues to the companies involved in the deal. On average, in the year of the deal, the average reve- nue of benchmark companies was $11.8 \%$ higher than the revenue of companies involved in the deal. For 9 out of 73 deals in the sample, the control group included 3 companies due to the lack of sufficient number of comparable companies.

If the companies involved in the deal operated in different industries, a benchmark portfolio of companies was formed for both the buyer and the target for the most relevant comparison. The operating profit margin of the control portfolios was weighted according to the revenues of the companies involved in the deal. This approach to benchmarking is similar to the method used in [23].

For example, for a deal between a target company with 2 billion rubles revenue and a buyer company in a different industry with 3 billion rubles revenue the control portfolio consists of 8 companies. The first 4 control companies will match with the industry of the target company and 2 billion rubles revenue. The next 4 control companies will match with the industry of the buyer company and 3 billion rubles revenue. The weight in the portfolio of the first 4 companies will be ( 2 billion rubles / 5 billion rubles $)=$ $40 \%$, the second 4 companies ( 3 billion rubles / 5 billion rubles) $=60 \%$. This calculation is made for each year of observation before and after the deal.

Summary statistics of explanatory variables are provided

\begin{tabular}{|c|c|c|c|c|c|c|}
\hline Variable & & Mean & Std. Dev. & Min & Max & Observations \\
\hline \multirow{3}{*}{$\begin{array}{l}\text { Operating profit margin } \\
\text { of companies in M\&A }\end{array}$} & overall & 0.107 & 0.117 & -0.051 & 0.332 & $\mathrm{~N}=443$ \\
\hline & between & & 0.100 & -0.051 & 0.332 & $\mathrm{n}=73$ \\
\hline & within & & 0.064 & -0.127 & 0.294 & $\mathrm{~T}$-bar $=6.110$ \\
\hline \multirow{3}{*}{$\begin{array}{l}\text { Real GDP growth in } \\
\text { Russia }\end{array}$} & overall & 0.011 & 0.020 & -0.025 & 0.043 & $\mathrm{~N}=446$ \\
\hline & between & & 0.004 & 0.000 & 0.014 & $\mathrm{n}=73$ \\
\hline & within & & 0.019 & -0.029 & 0.039 & $\mathrm{~T}-\mathrm{bar}=6.110$ \\
\hline \multirow{3}{*}{$\begin{array}{l}\text { Dummy variable for hori- } \\
\text { zontal M\&A }\end{array}$} & overall & 0.706 & 0.457 & 0.000 & 1.000 & $\mathrm{~N}=446$ \\
\hline & between & & 0.470 & 0.000 & 1.000 & $\mathrm{n}=73$ \\
\hline & within & & 0.000 & 0.706 & 0.706 & $\mathrm{~T}-\mathrm{bar}=6.217$ \\
\hline \multirow{3}{*}{$\begin{array}{l}\text { Natural logarithm of deal } \\
\text { value in mln USD }\end{array}$} & overall & 5.049 & 1.531 & 2.590 & 9.037 & $\mathrm{~N}=226$ \\
\hline & between & & 1.572 & 2.590 & 9.037 & $\mathrm{n}=38$ \\
\hline & within & & 0.000 & 5.049 & 5.049 & $\mathrm{~T}-\mathrm{bar}=5.947$ \\
\hline \multirow{3}{*}{$\begin{array}{l}\text { Natural logarithm of tar- } \\
\text { get company assets value } \\
\text { in mln RUB }\end{array}$} & overall & 8.764 & 1.721 & 3.481 & 13.291 & $\mathrm{~N}=446$ \\
\hline & between & & 1.692 & 4.457 & 13.001 & $\mathrm{n}=73$ \\
\hline & within & & 0.395 & 7.301 & 10.332 & $\mathrm{~T}-\mathrm{bar}=6.041$ \\
\hline
\end{tabular}
in Table 4.

Table 4. Summary statistics of variables in the baseline model

Source: Author's analysis. Note: 35 deals had no information about the deal value 
The significance of explanatory variables was assessed with a random individual effects data model. This model was chosen because of the presence of a time-independent dummy variable and was recommended by Breusch- $\mathrm{Pa}-$ gan and Hausman tests. Due to the presence of heteroscedasticity, the model was estimated using robust standard errors. No multicollinearity was found in the model with the variance inflation factor (VIF) test in Stata 14.

The general equation for the model is formulated as follows:

Operating profit margin $_{i t}=\alpha+\beta_{1} \times$ hypothesis $_{i t}+$ $+\beta_{2} \times$ control $_{i t}+u_{i}+\varepsilon_{i t}$

Where hypothesis is the set of explanatory variables for hypotheses testing, control is the set of control variables, $u$ is the set of individual effects and $\varepsilon$ is the random variable.

For robustness checks, the base model was estimated separately with three groups of control variables: characteristics of the deal, the target company and the buyer. The characteristic of the deal is the share in the equity of the target company after the deal. The characteristics of the target company are operating cash flow and capital expenditures. The characteristics of the buyer are operating cash flow, capital expenditures, the presence of a foreign shareholder in the equity capital and the presence of the government in the equity capital. This approach to robustness checks with groups of control variables is similar to the one proposed and used in [24].

\section{Results}

Median operating profit margin of the companies involved in the deal and the benchmark portfolio is provided in Figure 3.

Before the M\&A, the operating profit margin of the companies involved in the deal is lower than the benchmark portfolio. The difference ranges from $-5.1 \% 3$ years before the M\&A to $-2.2 \%$ in the year of the M\&A.

$M \& A$ deals lead to a significant improvement in the operating profit margin. Over 3 years after M\&A, operating profit margin increases from $7.7 \%$ to $12.3 \%$. The greatest effect relative to the benchmark portfolio is achieved 2 years after M\&A.

The improvement of operating profit margin occurs thanks to an abnormal increase in revenues in comparison to expenses. In the first year after M\&A, companies' revenues grew by $8.6 \%$, while operating expenses grew by $8.1 \%$. In the second year, revenue grew by $7.0 \%$, while expenses decreased by $0.8 \%$.

At a significance level of 5\% this supports the hypothesis that M\&As create opportunities for the company to receive excessive profit, in comparison to the control group of companies. This hypothesis was tested with the Wilcoxon test [25] for the operating profit margins of the companies involved in M\&A and operating profit margins of the matched benchmark portfolios.

Figure 3. Median operating profit margin for the companies involved in M\&A and the benchmark portfolio

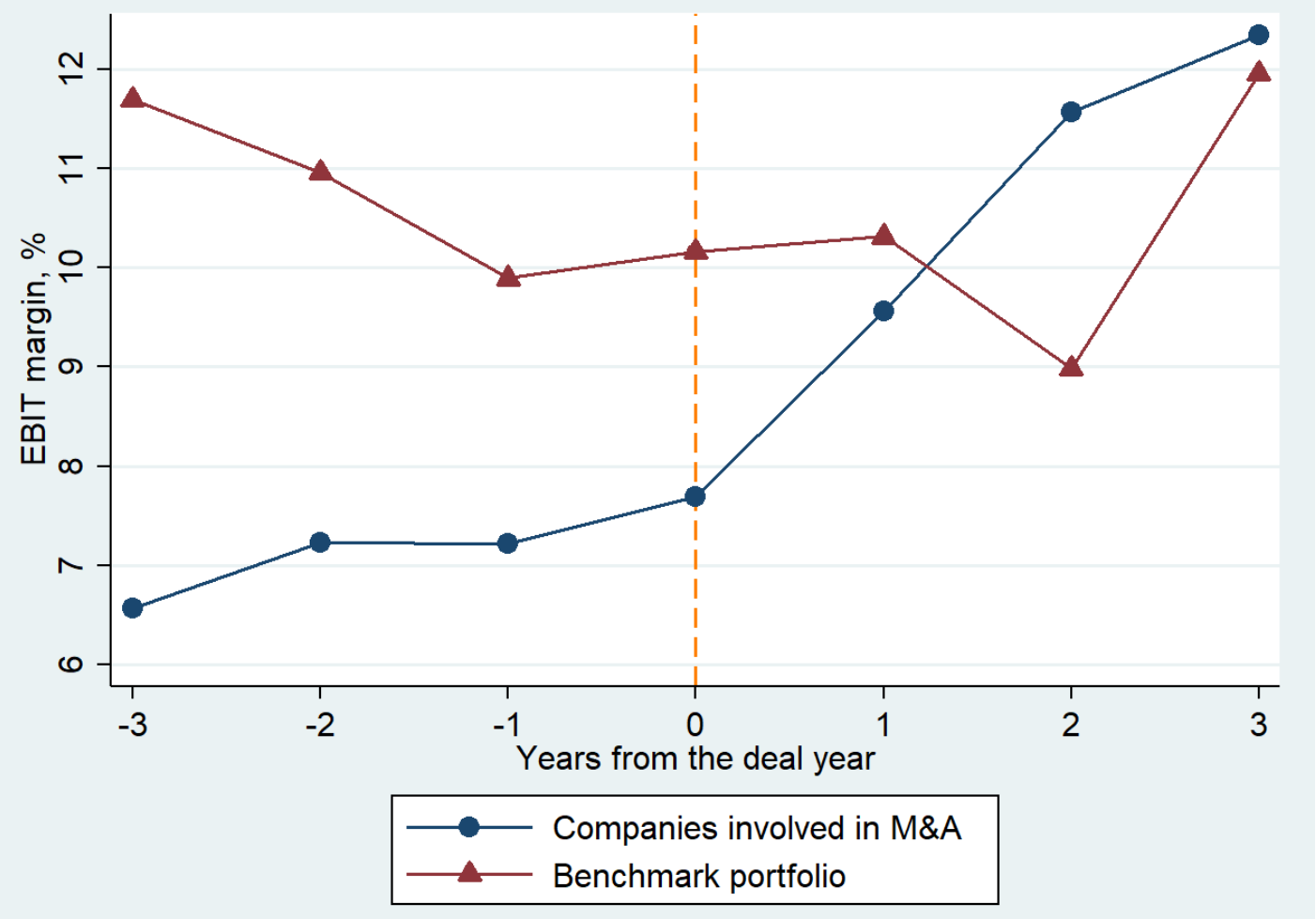

Source: Author's analysis 
The results of econometric testing of research hypotheses 2-5 are provided in Table 5.

The results show that M\&A between large companies in the same industry improve operating profit margin the most. According to the base model, horizontal M\&A lead to $11.4 \%$ increase in operating profit margin compared to vertical M\&A (10\% significance level). A $1 \%$ increase in the target company book value of assets leads to a $5.7 \%$ increase in operating profit margin ( $5 \%$ significance level). The decrease of operating profit margin is associated with the deal value: a $1 \%$ increase in the deal value leads to a $8.3 \%$ decrease in operating profit margin ( $1 \%$ significance level). In addition, the negative effect of the deal value is higher than the positive effect of the target asset value, which may indicate overpayment relative to the fair value by the buyers.

Models with three groups of control variables were additionally evaluated to test the robustness of the results. Robustness checks confirm the estimates obtained in the base model: signs and impact of significant variables in the base model do not change with the addition of control variables.

Thus, from the perspective of improving operating profit margin with domestic transactions, horizontal M\&A with large companies are the most attractive targets. At the same time, it is necessary to accurately assess the fair value of the target so that the deal value does not absorb potential synergy.

\section{Table 5. Econometric testing of research hypotheses}

\begin{tabular}{|c|c|c|c|c|}
\hline \multirow[t]{2}{*}{ Variable } & (1) & $(2)$ & (3) & $(4)$ \\
\hline & Baseline model & $\begin{array}{l}\text { First group of } \\
\text { control variables }\end{array}$ & $\begin{array}{l}\text { Second group of } \\
\text { control variables }\end{array}$ & $\begin{array}{l}\text { Third group of } \\
\text { control variables }\end{array}$ \\
\hline \multicolumn{5}{|c|}{ Baseline model with 4 explanatory variables } \\
\hline \multirow{2}{*}{ Real GDP growth } & -0.517 & -0.515 & -0.532 & -0.378 \\
\hline & $(0.507)$ & $(0.506)$ & $(0.591)$ & $(0.594)$ \\
\hline \multirow[t]{2}{*}{ Horizontal M\&A } & $0.114^{*}$ & $0.106^{*}$ & 0.109 & 0.149 \\
\hline & $(0.066)$ & $(0.063)$ & $(0.069)$ & $(0.094)$ \\
\hline \multirow[t]{2}{*}{ Natural logarithm of deal value } & $-0.083^{\star * *}$ & $-0.088^{* * *}$ & $-0.081^{\star * *}$ & $-0.082^{\star * *}$ \\
\hline & $(0.027)$ & $(0.028)$ & $(0.029)$ & $(0.027)$ \\
\hline \multirow{2}{*}{$\begin{array}{l}\text { Natural logarithm of target company } \\
\text { assets value }\end{array}$} & $0.057^{\star *}$ & $0.059^{\star *}$ & $0.056^{\star *}$ & $0.040^{* * *}$ \\
\hline & $(0.024)$ & $(0.025)$ & $(0.029)$ & $(0.015)$ \\
\hline \multicolumn{5}{|l|}{ Control variable for the deal } \\
\hline $\begin{array}{l}\text { Share in the equity of the target com- } \\
\text { pany after the deal }\end{array}$ & - & $\begin{array}{l}0,183 \\
(0,193)\end{array}$ & - & - \\
\hline
\end{tabular}

Control variables for the target company

Natural logarithm of operating cash -

flow of the target (0.009)

0.014

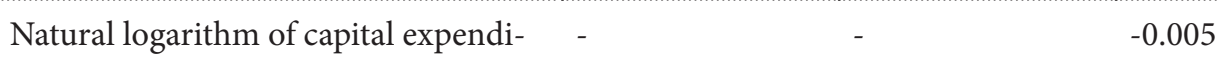

tures of the target $\quad(0.006)$

Control variables of the buyer company

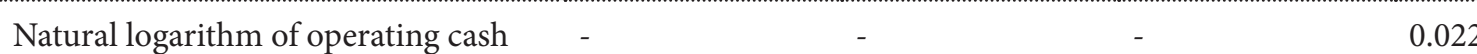

flow of the buyer $\quad(0.019)$

Natural logarithm of capital expendi- $\quad-\quad 10000$

$\begin{array}{ll}\text { tures of the buyer } & (0.005)\end{array}$

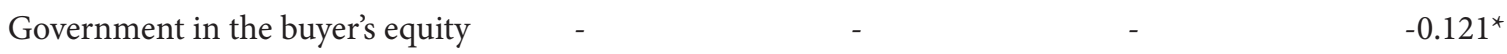

capital $(0.066)$

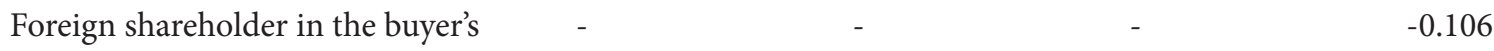

equity capital $(0.077)$ 


\begin{tabular}{|c|c|c|c|c|}
\hline Variable & (1) & (2) & (3) & $(4)$ \\
\hline & Baseline model & $\begin{array}{l}\text { First group of } \\
\text { control variables }\end{array}$ & $\begin{array}{l}\text { Second group of } \\
\text { control variables }\end{array}$ & $\begin{array}{l}\text { Third group of } \\
\text { control variables }\end{array}$ \\
\hline Control variables & Not included & Included & Included & Included \\
\hline Constant & $\begin{array}{l}-0,014 \\
(0,121)\end{array}$ & $\begin{array}{l}-0.171 \\
(0.203)\end{array}$ & $\begin{array}{l}-0,069 \\
(0.122)\end{array}$ & $\begin{array}{l}-0,027 \\
(0,087)\end{array}$ \\
\hline Observations & 446 & 446 & 446 & 446 \\
\hline Deals & 73 & 73 & 73 & 73 \\
\hline Significance (chi-squared) & $0,033^{* *}$ & $0,056^{*}$ & $0,000^{* * *}$ & $0,000^{* * *}$ \\
\hline Overall R-squared & 0,177 & 0,236 & 0,150 & 0,395 \\
\hline
\end{tabular}

Source: Author's analysis. Note: figures in brackets are the robust standard errors.

Significance levels: ${ }^{\star * \star} \mathrm{p}<0.01,{ }^{\star *} \mathrm{p}<0.05,{ }^{\star} \mathrm{p}<0.10$. Significance levels were calculated with $\mathrm{t}$ tests.

\section{Conclusion}

The result of the study was an assessment of the impact of domestic M\&A on operating profit margin and several explanatory factors according to the proposed methodology. The object of the study were Russian companies directly involved in domestic M\&A.

Based on the existing research, an approach to operating profit margin assessment was proposed. Changes in operating profit margin were assessed during 7 years of monitoring of companies involved in M\&A. An econometric model based on data with random individual effects was developed, the significance of explanatory factors was assessed.

The most salient result of the study is that there is a significant positive impact of M\&A on operating profit margin. Our evidence supports the view that M\&A can improve the operating performance of companies. In the domestic Russian M\&A market, the operating profit margin of companies improves after horizontal deals between large companies, in line with previous research of other M\&A markets ([15], [16], [17], [21]). However, in Russia, unlike many other countries (see [13]), real GDP growth does not impact the size of the national M\&A market in value terms or the operating profit margin of companies after deals.

One of the directions for development of this research is the addition of other explanatory variables in the econometric model. The developed methodology can also be applied to M\&A in other countries to analyse the features of other M\&A markets.

\section{References}

1. Barber B., Lyon J. Detecting long-run abnormal stock returns: The empirical power and specification of test statistics. Journal of Financial Economics. 1997;43(3):341-372. DOI: 10.1016/S0304405X(96)00890-2
2. Moeller S., Schlingemann F. Wealth destruction on a massive scale? A study of acquiring-firm returns in the recent merger wave. The Journal of Finance. 2005;60(2):757-782. DOI: 10.1111/j.15406261.2005.00745.x

3. Kaplan S., Weisbach M. The success of acquisitions: Evidence from divestitures. The Journal of Finance. 1992;47(1):107-138. DOI: 10.1111/j.1540-6261.1992. tb03980.x

4. Healy P., Palepu K., Ruback R. Does corporate performance improve after mergers? Journal of financial economics. 1992;31(2):135-175 DOI: 10.1016/0304-405X(92)90002-F

5. Golubov A., Nan X. Post-acquisition performance of private acquirers. Journal of Corporate Finance. 2020;60. DOI: 10.1016/j.jcorpfin.2019.101545

6. Blonigen B., Pierce J. Evidence for the effects of mergers on market power and efficiency. National Bureau of Economic Research. 2016;w22750:1-36. URL: https://www.nber.org/papers/w22750.pdf

7. Kyriazopoulos G., Drymbetas E. Do domestic banks mergers and acquisitions still create value? Recent evidence from Europe. Journal of Finance and Bank Management. 2015;3(1):100-116. DOI: 10.15640/ jfbm.v3n1a10

8. Buzzell R., Gale B., Sultan R. Market share - a key to profitability. Harvard Business Review. 1975;53(1):97106.

9. Faria A., Wellington W. Validating business simulations: does high market share lead to high profitability? Developments in Business Simulation and Experiential Learning. 2014;31:332-336.

10. Martin J., Voltes-Dorta A. International airports: economies of scale and marginal costs. Journal of the Transportation Research Forum. 2010;47(1):5-22. DOI: 10.5399/osu/jtrf.47.1.1056 
11. Beccalli E., Anolli M., Borello G. Are European banks too big? Evidence on economies of scale. Journal of Banking \& Finance. 2015;58: 232-246. DOI: 10.1016/j. jbankfin.2015.04.014

12. Kuternin M. Production functions of the russian economy sectors taking into account effect of economy at a scale. The State Univeristy of Management Journal. 2018;(3):90-97. (In Russian). DOI: 10.26425/1816-4277-2018-3-90-97

13. Reddy K., Nangia V., Agrawal R. The 2007-2008 global financial crisis, and cross-border mergers and acquisitions: A 26-nation exploratory study. Global Journal of Emerging Market Economies. 2014;6(3):1629. DOI: $10.1177 / 0974910114540720$

14. Goddard J., Molyneux P., Zhou T. Bank mergers and acquisitions in emerging markets: evidence from Asia and Latin America. The European Journal of Finance. 2012;18(5):419-438. DOI: 10.1080/1351847X.2011.601668

15. Ibrahimi M., Meghouar H. Sources of value creation and destruction in horizontal mergers and acquisitions. Managerial Finance. 2019;45(1011):1398-1415. DOI: 10.1108/MF-02-2018-0053

16. Chen Y., Lok C., Phua L., Quah K. The impact of mergers and acquisitions on financial performance of listed companies in China. International Journal of Entrepreneurship and Management Practices. 2019;8(2):01-12. DOI: 10.35631/ijemp.28001

17. Grigorieva S., Trotsky P. Impact of mergers and acquisitions on the operational efficiency of companies in emerging capital markets. Journal of Corporate Finance Research. 2012;23(3):31-43. (In Russian) DOI: 10.17323/j.jcfr.20730438.6.3.2012.31-43

18. Agliardi E., Lukyanova I. Evidence from Corporate Mergers: Leverage, Industry Characteristics and Returns' Moments. Journal of Corporate Finance Research. 2012;5(4):54-76. (In Russian) DOI: 10.17323/j.jcfr.2073-0438.5.4.2011.54-76

19. Rogova E., Luzina D. The Effect of Mergers and Acquisitions on companies' Fundamental Values in Emerging Capital Markets (the Case of BRICS). Journal of Corporate Finance Research. 2015;9(3):27-50. (In Russian) DOI: 10.17323/j. jcfr.2073-0438.9.3.2015.27-50

20. Grigorieva S., Grinchenko A. Impact of mergers and acquisitions in financial sector on bidder's returns in emerging capital markets. Journal of Corporate Finance Research. 2014;7(4):53-71. (In Russian) DOI: 10.17323/j.jcfr.2073-0438.7.4.2013.53-71
21. Rao-Nicholson R., Salaber J., Cao T. Long-term performance of mergers and acquisitions in ASEAN countries. Research in International Business and Finance. 2016;36:373-387. DOI: 10.1016/j. ribaf.2015.09.024

22. Penas M., Unal H. Gains in bank mergers: Evidence from the bond markets. Journal of Financial Economics. 2004;74(1):149-179. DOI: 10.1016/j. jfineco.2003.05.004

23. Megginson W., Morgan A., Nail L. The determinants of positive long-term performance in strategic mergers: Corporate focus and cash. Journal of Banking \& Finance. 2004;28(3):532-533. DOI: 10.1016/S0378-4266(02)00412-0

24. Gishan D., Drobetz W., Momtaz P. Competition policy and the profitability of corporate acquisitions. Journal of Corporate Finance. 2020;62. DOI: 10.1016/j.jcorpfin.2019.101510

25. Wilcoxon F. Individual Comparisons by Ranking Methods. Biometrics Bulletin. 1945;1(6):80-83. DOI: $10.2307 / 3001968$ 